\title{
The Effect of Stand Age on Throughfall Chemistry in Spruce Stands in the Potok Dupniański Catchment in the Silesian Beskid Mountains, Southern Poland
}

\author{
Stanisław Małek ${ }^{1, *}$ and Aleksander Astel ${ }^{2}$ \\ ${ }^{1}$ Department of Forest Ecology, Forest Faculty, Agricultural University of Cracow, Al. \\ 29 Listopada 46, 31-425 Kraków, Poland; ${ }^{2}$ Environmental Chemistry Research Unit, \\ Biology and Environmental Protection Institute, Pomeranian Academy, 22a \\ Arciszewskiego Str., 76-200 Słupsk, Poland \\ E-mail: rlmalek@cyf-kr.edu.pl; astel@pap.edu.pl
}

Received October 13, 2006; Revised February 23, 2007; Accepted February 23, 2007; Published March 21, 2007

The chemical composition of throughfall depends on the age of the Norway spruce (Picea abies Karst) stands and season of the year. The $\mathrm{pH}$ of throughfall decreased and the amount of hydrogen ion in throughfall deposited to the soil increased with increasing age of spruce stands, especially in the winter season. Concentrations of $\mathrm{K}^{+}, \mathrm{H}^{+}, \mathrm{SO}_{4}{ }^{2-}$, $\mathrm{Mn}^{2+}$, and $\mathrm{NH}_{4}^{+}$in throughfall were higher than bulk precipitation for the whole year and $\mathrm{K}^{+}, \mathrm{H}^{+}$, and $\mathrm{Mn}^{2+}$ concentrations were higher in throughfall in winter and the growing season. This indicates that these ions were washed out or washed from the surface of needles and/or the bark, and that $\mathrm{NO}_{3}{ }^{-}, \mathrm{NH}_{4}{ }^{+}, \mathrm{Ca}^{2+}, \mathrm{Mg}^{2+}, \mathrm{Fe}^{2+}$, and $\mathrm{Zn}^{2+}$ were absorbed in the canopy. The effect of high nitrogen deposition, above critical loads, and an increase in the amount of sulfur and in the sum of the strong acids $\left(\mathrm{S}-\mathrm{SO}_{4}{ }^{2-}\right.$ and $\left.\mathrm{N}-\mathrm{NO}_{3}{ }^{-}\right)$that reached the soil with throughfall may have implications for the vitality of spruce stands, especially in older age classes. The application of Principal Component Analysis (PCA) has led to identification of five factors responsible for the data structure ("mineral dust",

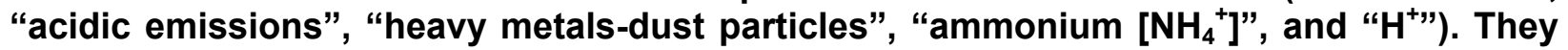
explain more than $60 \%$ of the total variance system. The strong positive correlation between stand age class and ionic concentrations in throughfall occurs for all year and the winter period for ions within the following categories: "acidic emissions", $\mathrm{SO}_{4}{ }^{2-}+$ $\mathrm{NO}_{3}{ }^{-}$; "heavy metals-dust particles", $\mathrm{Fe}^{2+}+\mathrm{Mn}^{2+}+\mathrm{Zn}^{2+}$; "mineral dust", $\mathrm{Na}^{+}+\mathrm{K}^{+}+\mathrm{Ca}^{2+}+$ $\mathrm{Mg}^{2+} ;$ " $\mathrm{NH}_{4}^{+}$"; and " $\mathrm{H}^{+}$". The strength of the relationship decreases in the growing period, probably due to processes occurring in the canopy (adsorption, leaching, etc.).

KEYWORDS: bulk precipitation, throughfall, Norway spruce stands, stand age, Silesian Beskid, southern Poland 


\section{INTRODUCTION}

Cycling of elements in Norway spruce (Picea abies Karst) stands, which are affected by industrial emissions, is still a subject of active research. The retention of considerable levels of contaminants by the canopy, and their removal or washout from needles by rainfall cause changes in the concentration of anions and cations reaching the soil surface[1]. Earlier investigations were based on relatively small forest catchments, such as Brenna[2,3,4], and on larger catchments, such as the Black and the White Vistula[5]. The goal of those studies was to estimate the volume and quality of the deposition of elements and their outflow from the catchment. Several case studies comparing elemental turnover in beech and spruce stands documented that, in general, deposition input to soil and the leaching of sulfur, nitrogen, and protons are higher in spruce stands[4]. Those studies did not usually take into account different development stages, either of stands or their spatial distribution in catchments. One study considered the effect of various development stages of spruce stands[1] and another one considered two different spruce age classes[6].

The present study examines the effect of different age classes (11-116 years) on throughfall chemistry in spruce stands in the Potok Dupniański catchment in the Silesian Beskid in the years 19992003. The objectives of this research were to determine: (1) if the chemical composition of throughfall water depends on the age of the spruce stands and season of the year, and (2) if the emission sources of the group of pollutants measured in the bulk precipitation (BP) and throughfall samples can be identified.

\section{METHODOLOGY, ANALYTICAL AND STATISTICAL TECHNIQUES}

The Potok Dupniański catchment, $1.68 \mathrm{~km}^{2}$ in area, is located in southern Poland in the Silesian Beskid Mts. (49 $\left.34^{\prime} \mathrm{N}, 18^{\circ} 50^{\prime} \mathrm{E}\right)$, not far from main industrial centers. This region of the Polish part of the Carpathian Mountains is under their negative effect[7,8]. The catchment is covered with Norway spruce (P. abies Karst) stands of different ages, growing on dystric cambisols developed on Istebna sandstone. The equipment for measuring throughfall in pure spruce stands (one monitoring plot in each age class) was set up in 1998. The $1^{\text {st }}, 2^{\text {nd }}, 5^{\text {th }}$, and $6^{\text {th }}$ age classes were $11,24,91$, and 116 years old, respectively, in 1999 (only one age class was found in each catchment). The descriptive characteristics of the spruce stands are presented in Table 1. A BP sampler was installed in the middle of the catchment at an elevation of $725 \mathrm{~m}$ a.s.1, close to the throughfall sampling point (within $500 \mathrm{~m}$ ). The studies were conducted in 1999-2003 following methods described in the ICP-Forest Manual (1998)[9] and by Małek[1].

During the vegetation season, from May $1^{\text {st }}$ to October $30^{\text {th }}$ (the same year), samples of bulk precipitation directly reaching the catchment were collected from special collectors (five units with $15-\mathrm{cm}$ inlet diameter each) installed in an open area $0.5 \mathrm{~m}$ above ground level, connected to a plastic tube with an outlet joining a container and a measuring device installed in a bunker. In winter, from November $1^{\text {st }}$ (the previous year) to April $30^{\text {th }}$ (the following year), six collectors (plastic, chemically neutral snow bags with $15-\mathrm{cm}$ inlet diameter each) were installed at $1.3 \mathrm{~m}$ above ground level in the open area at a distance of 120-150 m from the forest edge. In order to evaluate the volume and quality of throughfall, water was sampled from a sampling system (this time, the number of collectors was 15 , each with a $15-\mathrm{cm}$ inlet diameter) installed under the canopy, similar to the one installed in the open area during the vegetation season. In winter, six collectors (plastic, chemically neutral snow bags with $15-\mathrm{cm}$ inlet diameter each) were installed at $1.3 \mathrm{~m}$ above ground level in spruce stands of different age classes (described in detail by Małek[1]).

The sampling was performed on the $1^{\text {st }}$ day of each month. Water was analyzed using ion chromatography (Dionex-320) to determine the concentration of $\mathrm{Cl}^{-}, \mathrm{NO}_{3}^{-}, \mathrm{SO}_{4}{ }^{2-}, \mathrm{F}^{-}, \mathrm{NH}_{4}^{+}, \mathrm{Na}^{+}, \mathrm{K}^{+}$, $\mathrm{Ca}^{2+}, \mathrm{Mg}^{2+}, \mathrm{Fe}^{2+}, \mathrm{Mn}^{2+}$, and $\mathrm{Zn}^{2+}$. A low-pH acid rain sample from southern Ontario (Canada), RAIN.97 No 409, served as a certified reference material (CRM) and was analyzed as well. When the concentration of analytes was below the limit of detection (LOD) of the analytical technique, the value of one-third LOD was used in the dataset due to chemometric requirements[10]. The limit of detection, expressed as 
TABLE 1

Descriptive Characteristics of Norway Spruce (P. abies Karst) Stands with Throughfall Plots in the Dupniański Stream Catchment

\begin{tabular}{lcccccc}
\hline Kind of Plot & $\begin{array}{c}\text { Age } \\
(\text { year })\end{array}$ & $\begin{array}{c}\text { Elevation } \\
(\mathbf{m} \text { a.s.I.) }\end{array}$ & $\begin{array}{c}\text { Diameter } \\
\left(\mathbf{m}^{-2}\right)\end{array}$ & $\begin{array}{c}\text { Height } \\
(\mathbf{m})\end{array}$ & $\begin{array}{c}\text { Number of } \\
\text { trees (no/1 ha) }\end{array}$ & $\begin{array}{c}\text { LAl (Leaf } \\
\text { Area Index) }\end{array}$ \\
\hline & & & $\mathbf{1 9 9 9}$ & & & \\
$1^{\text {st }}$ age class & 11 & 720 & 2.2 & 1.5 & 20,150 & 5.0 \\
$2^{\text {nd }}$ age class & 24 & 700 & 11.7 & 12.6 & 2,611 & 5.3 \\
$5^{\text {th }}$ age class & 91 & 660 & 39.7 & 37.8 & 382 & 5.4 \\
$6^{\text {th }}$ age class & 116 & 700 & 42.1 & 36.6 & 414 & 5.5 \\
& & & 2003 & & & \\
$1^{\text {st }}$ age class & 16 & & 3.6 & 5 & 13,758 & 5.1 \\
$2^{\text {nd }}$ age class & 29 & & 14.7 & 16.2 & 2,070 & 5.3 \\
$5^{\text {th }}$ age class & 96 & & 42.1 & 39.1 & 350 & 5.4 \\
$6^{\text {th }}$ age class & 121 & & 45.5 & 38.8 & 330 & 5.5 \\
\hline
\end{tabular}

concentration or quantity, is derived from the smallest quantity that can be detected with reasonable certainty for a given procedure[11]. Replacement values were used in 1, 3, 29, and 16 samples used for the determination of $\mathrm{K}^{+}, \mathrm{Mg}^{2+}, \mathrm{Zn}^{2+}, \mathrm{Mn}^{2+}$, respectively. In the dataset, there were two variables with significantly high percentage of measurements below LOD $\left(\mathrm{Fe}^{2+}, \mathrm{F}^{-}\right)$. One of the ions $\left(\mathrm{Fe}^{2+}-25 \%\right.$ measurements below LOD) was subjected to chemometrical evaluation mainly due to the small value of the mean and the median. Data for $\mathrm{F}^{-}$were excluded from the analyses.

A commercial statistics software package, Statistica 6.0 for Windows, was used for chemometric data mining[12]. Before chemometrical evaluation, the data were normalized by logarithmic transformation in the form $x^{\prime}=\log (x)$ for ion concentration, due to considerable asymmetry of analyte concentration values. Analysis of variance was performed on logarithmic concentration values after dividing the whole set into two additional subsets concerning winter (from November to April) and the vegetation season (from May to October). Moreover, autoscaling was performed prior to Principal Component Analysis (PCA) evaluation. The validation of the obtained PC models was performed by consideration of the scree plot (empirical testing) and only those PCs were included in the model, which possess eigenvalues greater than or close to 1 . Significance of the component model retained was additionally tested by applying Bartlett's statistics[13] and the model with three components was selected for the $5^{\text {th }}$ forest stand age class category, four PCs for BP, and five PCs for the $1^{\text {st }}, 2^{\text {nd }}$, and $6^{\text {th }}$ forest age class categories, which in general confirms scree plot analysis results[13]. Factors obtained by PCA were rotated using the orthogonal varimax rotation.

\section{RESULTS AND DISCUSSION}

After passing through the canopy (Table 2), water decreased its $\mathrm{pH}$ value: in winter - from 5.09 (in BP) to 4.97 (stands of $1^{\text {st }}$ age class), 4.60 ( $2^{\text {nd }}$ age class), 4.21 ( $5^{\text {th }}$ age class), and 4.11 ( $6^{\text {th }}$ age class); in the growing season - from 5.25 (in BP) to 5.04 ( $1^{\text {st }}$ age class), 4.99 ( $2^{\text {nd }}$ age class), 4.42 ( $5^{\text {th }}$ age class), and 4.41 ( $6^{\text {th }}$ age class), indicating that decreasing $\mathrm{pH}$ and an increasing amount of hydrogen ion was deposited to the soil in throughfall with increasing stand age, especially in the winter season. 
TABLE 2

Five-Year Average (1999-2003) Deposition Fluxes in BP and Throughfall Water in Different Norway Spruce $\left(P\right.$. abies Karst) Stand Age Classes $\left(1^{\text {st }}, 2^{\text {nd }}, 5^{\text {th }} \text {, and } 6^{\text {th }}\right)^{*}($ in $\mathrm{kg} / \mathrm{ha})$ and $\mathrm{pH}$ of Water in the Dupniański Stream Catchment in Particular Seasons

\begin{tabular}{|c|c|c|c|c|c|c|c|c|c|c|c|c|c|c|}
\hline \multirow{2}{*}{$\begin{array}{l}\text { Kind } \\
\text { of } \\
\text { Water }\end{array}$} & \multirow{2}{*}{$\underset{(\mathrm{mm})}{V}$} & $\mathrm{Cl}^{-}$ & $\mathrm{N}-\mathrm{NO}_{3}^{-}$ & $\mathrm{N}-\mathrm{NH}_{4}^{+}$ & $\mathrm{S}-\mathrm{SO}_{4}{ }^{2-}$ & $\mathrm{Na}^{+}$ & $\mathrm{K}^{+}$ & $\mathrm{Ca}^{2+}$ & $\mathrm{Mg}^{2+}$ & $\mathrm{Fe}^{2+}$ & $\mathrm{Mn}^{2+}$ & $\mathrm{Zn}^{2+}$ & \multirow{2}{*}{$\begin{array}{c}\mathrm{H}^{+} \\
\left(\mathrm{g} \mathrm{ha}^{-1}\right)\end{array}$} & \multirow[b]{2}{*}{$\mathrm{pH}$} \\
\hline & & \multicolumn{11}{|c|}{$\left(\mathrm{kg} \mathrm{ha}^{-1}\right)$} & & \\
\hline \multicolumn{15}{|c|}{ Whole Year } \\
\hline BP & 1,072 & 19.70 & 9.02 & 12.24 & 13.67 & 7.67 & 9.17 & 32.73 & 4.41 & 0.52 & 0.17 & 2.34 & 70.82 & 5.18 \\
\hline $1^{\text {st }}$ & 933 & 9.27 & 5.80 & 9.26 & 10.98 & 4.14 & 11.14 & 16.13 & 2.09 & 0.44 & 0.45 & 0.30 & 92.75 & 5.00 \\
\hline $2^{\text {nd }}$ & 833 & 14.08 & 8.53 & 8.30 & 15.99 & 5.43 & 19.59 & 17.79 & 2.24 & 0.49 & 0.62 & 0.33 & 148.28 & 4.75 \\
\hline $5^{\text {th }}$ & 696 & 10.25 & 6.84 & 9.61 & 17.54 & 3.22 & 16.00 & 19.12 & 2.71 & 0.34 & 1.98 & 0.41 & 332.30 & 4.32 \\
\hline $6^{\text {th }}$ & 624 & 10.96 & 6.78 & 9.50 & 17.28 & 3.38 & 12.87 & 20.96 & 3.04 & 0.41 & 0.88 & 0.43 & 342.00 & 4.26 \\
\hline \multicolumn{15}{|c|}{ Growing Season } \\
\hline $\mathrm{BP}$ & 639 & 14.43 & 6.45 & 7.67 & 8.60 & 3.71 & 6.93 & 22.87 & 2.79 & 0.39 & 0.11 & 2.15 & 35.56 & 5.25 \\
\hline $1^{\text {st }}$ & 475 & 4.41 & 3.31 & 5.11 & 6.88 & 2.12 & 9.47 & 9.53 & 1.26 & 0.25 & 0.35 & 0.17 & 43.48 & 5.04 \\
\hline $2^{\text {nd }}$ & 412 & 7.73 & 5.07 & 4.95 & 7.75 & 3.41 & 15.10 & 9.37 & 1.11 & 0.27 & 0.38 & 0.12 & 41.71 & 4.99 \\
\hline $5^{\text {th }}$ & 399 & 4.99 & 4.11 & 5.86 & 8.93 & 1.50 & 10.68 & 10.03 & 1.23 & 0.22 & 0.91 & 0.23 & 150.72 & 4.42 \\
\hline $6^{\text {th }}$ & 364 & 4.92 & 3.52 & 5.82 & 8.69 & 1.51 & 8.52 & 11.20 & 1.64 & 0.25 & 0.38 & 0.21 & 140.52 & 4.41 \\
\hline \multicolumn{15}{|c|}{ Winter Season } \\
\hline $\mathrm{BP}$ & 432 & 5.27 & 2.57 & 4.56 & 5.07 & 3.96 & 2.24 & 9.87 & 1.62 & 0.13 & 0.07 & 0.19 & 35.26 & 5.09 \\
\hline $1^{\text {st }}$ & 457 & 4.87 & 2.50 & 4.15 & 4.10 & 2.02 & 1.68 & 6.60 & 0.83 & 0.19 & 0,10 & 0.13 & 49.27 & 4.97 \\
\hline $2^{\text {nd }}$ & 421 & 6.35 & 3.46 & 3.35 & 8.24 & 2.01 & 4.48 & 8.42 & 1.13 & 0.22 & 0.25 & 0.20 & 106.57 & 4.60 \\
\hline $5^{\text {th }}$ & 297 & 5.27 & 2.72 & 3.76 & 8.61 & 1.72 & 5.32 & 9.09 & 1.48 & 0.12 & 1.07 & 0.18 & 181.59 & 4.21 \\
\hline $6^{\text {th }}$ & 260 & 6.05 & 3.27 & 3.67 & 8.59 & 1.87 & 4.36 & 9.76 & 1.40 & 0.16 & 0.51 & 0.22 & 201.49 & 4.11 \\
\hline
\end{tabular}

* The four stand age categories correspond to stands that are 11, 24, 91, and 116 years old.

Concentrations of $\mathrm{K}^{+}, \mathrm{H}^{+}, \mathrm{SO}_{4}{ }^{2-}, \mathrm{Mn}^{2+}$, and $\mathrm{NH}_{4}{ }^{+}$in throughfall were higher than $\mathrm{BP}$ for the whole year, and $\mathrm{K}^{+}, \mathrm{H}^{+}$, and $\mathrm{Mn}^{2+}$ concentrations were higher in throughfall in winter and the growing season. These results indicate that these ions were washed out or washed from the surface of needles and/or the bark. The other ions, $\mathrm{NO}_{3}^{-}, \mathrm{NH}_{4}{ }^{+}, \mathrm{Ca}^{2+}, \mathrm{Mg}^{2+}$ (especially in vegetation period), $\mathrm{Fe}^{2+}$, and $\mathrm{Zn}^{2+}$, were absorbed by the canopy (Table 2, Figs. 1 and 2). A substantial absorption of nitrate, especially during the growing season, confirms the results of Lovett at al.[14]. In the stands of the $2^{\text {nd }}$ age class, up to $80 \%$ of nitrogen was absorbed in tree crowns, a value similar to the one established by Zimka and Stachurski[15].

Tree crowns, and especially needle surfaces, are places where dust pollutants, particularly heavy metals, such as $\mathrm{Zn}$ and $\mathrm{Cd}$, are deposited[16]. These pollutants are removed from canopies by precipitation. The effectiveness of their removal differs according to the ion and tree species[17]. It also depends on other factors, namely the presence of $\mathrm{NH}_{4}{ }^{+}$ions and epiphytes, the concentration of elements in the foliage, and on ion exchange reactions. These reactions make it possible for plants to take up elements directly from rainwater, which causes the removal of $\mathrm{Na}^{+}, \mathrm{K}^{+}$, and $\mathrm{Zn}^{2+}$ from the plants, thus intensifying the transfer of those ions to the soil[18]. In the case of spruce stands growing in the Potok Dupniański catchment, concentrations of $\mathrm{K}^{+}$and $\mathrm{Mn}^{2+}$ in throughfall were higher than in BP for all stand ages, as in the year 2000[1]. Magnesium and calcium are probably absorbed directly from rainfall, possibly compensating for the considerable washout of these elements beyond the reach of the root system[5].

The effect of nitrogen deposition may be an increasing problem in the future unless emissions of nitrogen oxides and especially of $\mathrm{NH}_{4}{ }^{+}$are reduced[19]. Five-year average bulk deposition to the Dupniański catchment in $\mathrm{kg} / \mathrm{ha} /$ year of sulfur $\left(\mathrm{S}^{-\mathrm{SO}_{4}}{ }^{2-}\right)$ was 13.7 , whereas in throughfall in each particular spruce age class, it was, respectively, $1^{\text {st }}$ age class, $11.0 ; 2^{\text {nd }}$ age class, $16.0 ; 5^{\text {th }}$ age class, 17.5; and $6^{\text {th }}$ age class, 17.3; indicating an increasing amount of sulfur with the spruce age especially in winter 


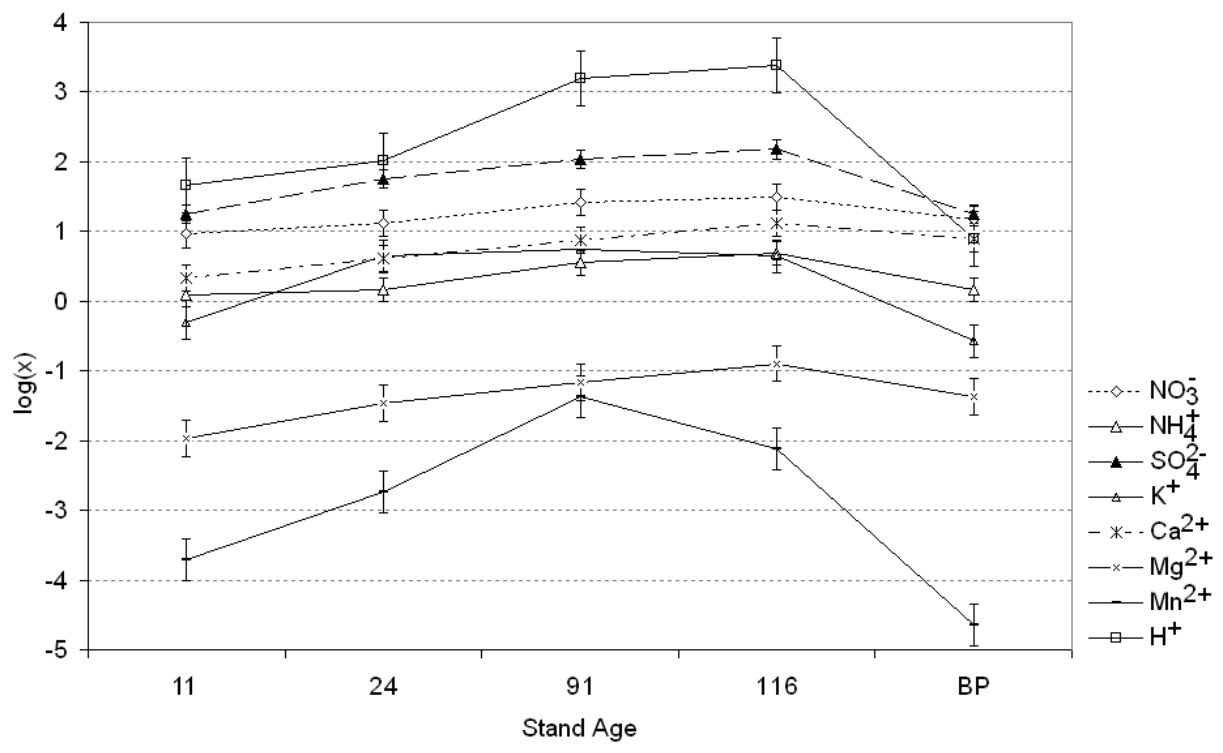

FIGURE 1. Distribution of logarithms of mean concentrations of $\mathrm{NO}_{3}^{-}, \mathrm{NH}_{4}^{+}, \mathrm{SO}_{4}{ }^{2-}, \mathrm{K}^{+}, \mathrm{Ca}^{2+}, \mathrm{Mg}^{2+}$, $\mathrm{Mn}^{2+}$ (all ions in $\left.\mathrm{mg} \cdot \mathrm{l}^{-1}\right)$, and $\mathrm{H}^{+}\left(\mu \mathrm{g} \cdot \mathrm{l}^{-1}\right)$ in throughfall for four Norway spruce (P. abies Karst) forest stand categories and in BP for the whole year (vertical lines represent confidence intervals, $p=0.05$ ).
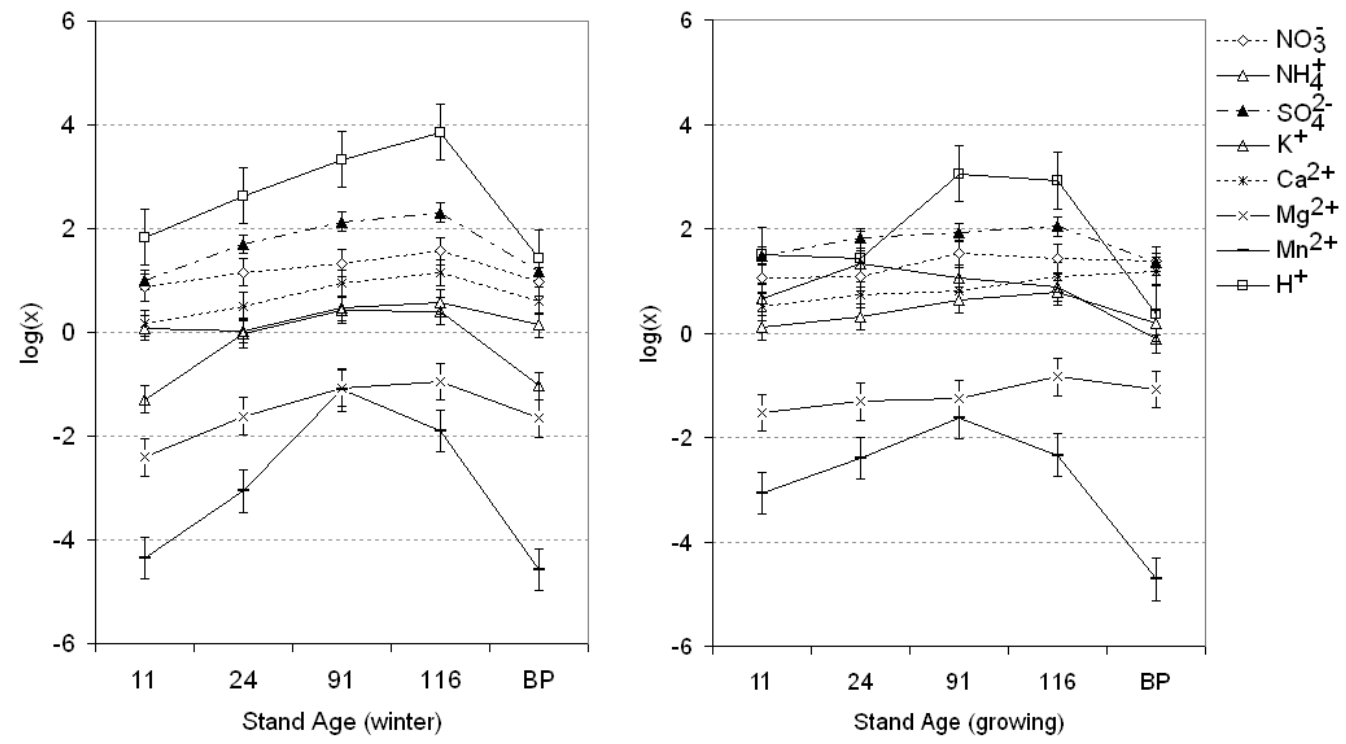

FIGURE 2. Distribution of logarithms of mean concentrations of $\mathrm{NO}_{3}{ }^{-}, \mathrm{NH}_{4}{ }^{+}, \mathrm{SO}_{4}{ }_{4}^{2-}, \mathrm{K}^{+}, \mathrm{Ca}^{2+}, \mathrm{Mg}^{2+}, \mathrm{Mn}^{2+}$ (all ions in $\left.\mathrm{mg} \cdot \mathrm{l}^{-1}\right)$, and $\mathrm{H}^{+}\left(\mu \mathrm{g} \cdot \mathrm{l}^{-1}\right)$ in throughfall for four Norway spruce (P. abies Karst) forest stand categories, stand age categories, and in BP in winter and in the growing season (vertical lines represent confidence intervals, $p=0.05$ ).

period. The sum of the strong acids $\left(\mathrm{S}_{-} \mathrm{SO}_{4}{ }^{2-}\right.$ and $\left.\mathrm{N}-\mathrm{NO}_{3}{ }^{-}\right)$in bulk deposition was around $22.7 \mathrm{~kg} / \mathrm{ha} / \mathrm{year}$, but in throughfall was around 24.5 in older spruce age classes (Table 2). Nitrogen deposition (sum N$\mathrm{NO}_{3}{ }^{-}$and $\mathrm{N}_{-} \mathrm{NH}_{4}{ }^{+}$) was above the critical load (15-20 kg N/ha/year) for coniferous trees, which may change $\mathrm{N} /$ macronutrients ratios, decrease $\mathrm{K}$ and $\mathrm{Mg}$, and increase $\mathrm{N}$ concentration in foliar tissue[20]. Nitrogen deposition fluxes in this study were below the values reported for the heavily polluted Ore Mts. (Czech Republic)[21]. 
Despite large emission reductions, the Dupniański Stream catchment still suffers from very high loads of acidifying input deposited during the past decades. Soil recovery depends on future emissions, especially on base cation deposition. The recovery will be even slower if base cation deposition decreases further[22]. The soil in the Dupniański catchment is very acidic and has relatively small pools of exchangeable $\mathrm{Ca}^{2+}$ and $\mathrm{Mg}^{2+}$. The trees show medium to severe nutrient deficiency symptoms, such as needle loss and needle yellowing[23]. Soil solution concentrations of $\mathrm{SO}_{4}{ }^{2-}, \mathrm{Ca}^{2+}$, and $\mathrm{Mg}^{2+}$ have generally decreased, while $\mathrm{pH}$ values remained stable throughout the study period, similar to that reported for Fichtelgebirge-NE-Bavaria, Germany[24]. Decreasing concentrations of cations in soil solution occurred especially in the growing period, which can affect nutrient cycling and mineral nutrition. This is of particular concern because magnesium is necessary for the proper development of plants (and whose deficit was observed in the same spruce stands in earlier studies[23]), along with the accumulation of heavy metals. The relatively low $\mathrm{pH}$ in throughfall may contribute to the release of heavy metals in the sorption complex of soil, which can adversely affect the development and health of spruce stands.

Ionic concentrations in BP and throughfall with varying stand ages are presented in Figs. 1 and 2 for $\mathrm{NO}^{3-}$, $\mathrm{NH}_{4}{ }^{+}, \mathrm{SO}_{4}{ }^{2-}, \mathrm{K}^{+}, \mathrm{Ca}^{2+}, \mathrm{Mg}^{2+}, \mathrm{Mn}^{2+}$, and $\mathrm{H}^{+}$. The lines connecting the mean value points were drawn for illustrative purposes only and do not convey mathematical meaning. In data from the whole year, there were significant differences between the youngest (the $1^{\text {st }}$ age class) and the older $5^{\text {th }}$ and $6^{\text {th }}$ age classes for all analyzed elements, and between the $2^{\text {nd }}$ and the $6^{\text {th }}$ age class (with exception for $\mathrm{K}^{+}$). Only a few significant differences were noticed between the $2^{\text {nd }}$ and the $5^{\text {th }}$ age class (for $\mathrm{NH}_{4}{ }^{+}, \mathrm{SO}_{4}{ }^{2-}, \mathrm{Mn}^{2+}$, and $\mathrm{H}^{+}$) and between the $1^{\text {st }}$ and the $2^{\text {nd }}$ age class (for $\mathrm{SO}_{4}{ }^{2-}, \mathrm{K}^{+}, \mathrm{Ca}^{2+}, \mathrm{Mg}^{2+}, \mathrm{Mn}^{2+}$ ). Between the 116- and the 91year-old spruce stands, we noticed a significant difference only for $\mathrm{Mn}^{2+}$. Taking into consideration the winter season, there was a significant difference between the youngest age class $\left(1^{\text {st }}\right)$ and the oldest $\left(5^{\text {th }}\right)$ and $\left(6^{\text {th }}\right)$, and between the $2^{\text {nd }}$ age class and the oldest for all analyzed elements. Only a few significant differences were noticed between the $2^{\text {nd }}$ and the $5^{\text {th }}$ age class (for $\mathrm{NH}_{4}{ }^{+}, \mathrm{SO}_{4}{ }^{2-}, \mathrm{K}^{+}, \mathrm{Ca}^{2+}, \mathrm{Mg}^{2+}, \mathrm{Mn}^{2+}$ ) and between the $1^{\text {st }}$ and the $2^{\text {nd }}$ age class (for $\mathrm{SO}_{4}{ }^{2-}, \mathrm{K}^{+}, \mathrm{Ca}^{2+}, \mathrm{Mg}^{2+}, \mathrm{Mn}^{2+}$ ). Between the oldest spruce stands $\left(5^{\text {th }}\right.$ and $6^{\text {th }}$ age classes), we noticed a difference only for $\mathrm{Mn}^{2+}$. In the vegetation period, there was a significant difference in the concentration of anions and cations between the youngest age class and the oldest $\left(5^{\text {th }}\right.$, with exception for $\mathrm{K}^{+}$, and $\left.6^{\text {th }}\right)$, and the $2^{\text {nd }}$ age class and the oldest (with exception for $\mathrm{NO}_{3}^{-}$, $\mathrm{NH}_{4}{ }^{+}$, and $\mathrm{Mn}^{2+}$ ). Only a few significant differences were noticed between the $2^{\text {nd }}$ and the $5^{\text {th }}$ age class (for $\mathrm{SO}_{4}{ }^{2-}, \mathrm{K}^{+}, \mathrm{Mn}^{2+}$, and $\mathrm{H}^{+}$) and between the $1^{\text {st }}$ and the $2^{\text {nd }}$ age class (for $\mathrm{SO}_{4}{ }^{2-}$ ). Between the oldest spruce stands $\left(5^{\text {th }}\right.$ and $6^{\text {th }}$ age classes), there was a difference for $\mathrm{SO}_{4}{ }^{2-}, \mathrm{K}^{+}, \mathrm{Ca}^{2+}, \mathrm{Mg}^{2+}$, and $\mathrm{Mn}^{2+}$.

Detection and assessment of the capacity of the forest canopies of stands of different ages to modify ionic solutions as they move through the canopy was evaluated by PCA. The goal of the PCA is to achieve data projection, matrix dimensionality reduction (in sense of the monitoring dataset), and to offer a model for data interpretation. The factor layout obtained by PCA for both precipitation and throughfall solutions was similar for four stand age classes. It explained 67.60, 75.84, 74.34, 61.26, and 68.09\% of the total variance system for BP and the $1^{\text {st }}, 2^{\text {nd }}, 5^{\text {th }}$, and $6^{\text {th }}$ age classes, respectively (Table 3 ). Five significant factors were obtained for the $1^{\text {st }}$ and $2^{\text {nd }}$ age classes, four factors for BP and the $6^{\text {th }}$ age class, and three in the case of the $5^{\text {th }}$ age class. The factor conditionally named as "mineral dust", referring to soil-dust particles, explains $27.71(\mathrm{BP}), 20.59\left(1^{\text {st }}\right), 15.95\left(2^{\text {nd }}\right), 17.38\left(5^{\text {th }}\right)$, and $32.30 \%\left(6^{\text {th }}\right)$ of the total variance and was strongly correlated with $\mathrm{Na}^{+}, \mathrm{K}^{+}, \mathrm{Ca}^{2+}$, and $\mathrm{Mg}^{2+}$, especially in older age classes and BP. Apart from a lack of correlation between $\mathrm{K}^{+}$and $\mathrm{Ca}^{2+}$ with other cations, the composition of the "mineral dust" factor is quite similar for the various forest stand age categories. This is in agreement with results obtained by others[25,26]. The factor conditionally named as "acidic emissions", referring to coemission of $\mathrm{SO}_{4}{ }^{2-}$ and $\mathrm{NO}_{3}^{-}$precursors $\left(\mathrm{SO}_{2}, \mathrm{NO}_{\mathrm{x}}\right)$ associated with the combustion of fossil fuels, burning of biomass, and by automobile exhaust, explains $19.98(\mathrm{BP}), 26.72\left(1^{\text {st }}\right), 12.28\left(2^{\text {nd }}\right)$, and $34.03 \%\left(5^{\text {th }}\right)$ of the total variance and was in most cases strongly correlated with $\mathrm{Cl}^{-}, \mathrm{SO}_{4}{ }^{2-}$, and $\mathrm{NO}_{3}{ }^{-}$. In the case of the $5^{\text {th }}$ age class category, this factor is supplemented by strongly correlated $\mathrm{NH}_{4}{ }^{+}$. The factor conditionally named as "heavy metals-dust particles", referring to heavy metals connected with ash emissions, explains $8.48(\mathrm{BP}), 8.14\left(1^{\mathrm{st}}\right), 28.76\left(2^{\mathrm{nd}}\right), 34.03\left(5^{\text {th }}\right)$, and $16.64 \%\left(6^{\text {th }}\right)$ of the total variance and includes strong correlations with $\mathrm{Fe}^{2+}, \mathrm{Mn}^{2+}$, and $\mathrm{Zn}^{2+}$. The $\mathrm{PC} 1$ structure for the $5^{\text {th }}$ category indicates an influence of 
TABLE 3

Factor Loading and Explained Variance for BP and Four Categories of Throughfall Solutions Collected from the Norway Spruce ( $P$. abies Karst) Forest Stands of Different Ages and Categories $\left(1^{\text {st }}, 2^{\text {nd }}, 5^{\text {th }}, 6^{\text {th }}\right)^{*}$ in the Dupniański Stream Catchment (1999-2003)

\begin{tabular}{|c|c|c|c|c|c|c|c|c|c|c|c|c|c|c|c|c|c|c|c|c|c|}
\hline & \multirow{2}{*}{\multicolumn{4}{|c|}{$\begin{array}{c}\text { Precipitation } \\
\text { BP }\end{array}$}} & \multicolumn{17}{|c|}{ Throughfall Solutions } \\
\hline & & & & & \multicolumn{5}{|c|}{$1^{\text {st }}$} & \multicolumn{5}{|c|}{$2^{\text {nd }}$} & \multicolumn{3}{|c|}{$5^{\text {th }}$} & \multicolumn{4}{|c|}{$6^{\text {th }}$} \\
\hline & PC1 & PC2 & PC3 & PC4 & PC2 & PC1 & PC3 & PC5 & PC4 & PC2 & PC3 & PC4 & PC1 & PC5 & PC2 & PC1 & PC3 & PC1 & PC4 & PC2 & PC3 \\
\hline & PC1 & PC2 & PC3 & PC4 & PC1 & PC2 & PC3 & PC4 & PC5 & PC1 & PC2 & PC3 & PC4 & PC5 & PC1 & PC2 & PC5 & PC1 & PC2 & PC4 & PC5 \\
\hline$V\left(m m \cdot m^{2}\right)$ & 0.18 & -0.57 & 0.04 & -0.34 & 0.18 & -0.61 & 0.05 & -0.41 & 0.01 & -0.35 & -0.46 & -0.18 & -0.38 & -0.33 & -0.07 & -0.71 & 0.30 & -0.11 & -0.81 & -0.29 & 0.02 \\
\hline $\mathrm{Cl}^{-}\left(\mathrm{mg} \cdot \mathrm{l}^{-1}\right)$ & 0.21 & 0.72 & 0.06 & 0.12 & 0.28 & -0.02 & 0.70 & 0.39 & 0.26 & -0.17 & 0.87 & 0.24 & 0.01 & 0.10 & 0.18 & 0.69 & -0.10 & 0.03 & 0.61 & 0.15 & 0.55 \\
\hline $\mathrm{NO}_{3}^{-}\left(\mathrm{mg} \cdot \mathrm{l}^{-1}\right)$ & 0.11 & 0.86 & -0.08 & 0.11 & 0.04 & 0.81 & 0.01 & -0.04 & 0.29 & 0.12 & 0.87 & 0.01 & -0.01 & -0.08 & 0.24 & 0.68 & 0.25 & 0.42 & 0.41 & -0.30 & 0.39 \\
\hline $\mathrm{NH}_{4}^{+}\left(\mathrm{mg} \cdot \cdot^{-1}\right)$ & -0.17 & 0.23 & 0.81 & -0.19 & -0.22 & 0.12 & 0.91 & -0.15 & -0.12 & 0.10 & 0.27 & 0.64 & 0.48 & -0.22 & 0.02 & 0.75 & -0.24 & 0.29 & 0.71 & 0.03 & -0.16 \\
\hline $\mathrm{SO}_{4}{ }^{2-}\left(\mathrm{mg} \cdot \mathrm{l}^{-1}\right)$ & 0.35 & 0.63 & 0.24 & 0.16 & 0.12 & 0.84 & 0.26 & 0.16 & 0.02 & 0.17 & 0.82 & 0.02 & 0.19 & 0.14 & 0.60 & 0.65 & 0.18 & 0.48 & 0.59 & 0.17 & 0.43 \\
\hline $\mathrm{Na}^{+}\left(\mathrm{mg} \cdot \cdot^{-1}\right)$ & 0.80 & -0.13 & -0.16 & -0.06 & 0.87 & -0.11 & -0.12 & -0.19 & 0.14 & 0.30 & 0.43 & 0.16 & -0.69 & -0.09 & 0.71 & -0.18 & 0.18 & 0.63 & 0.04 & -0.26 & 0.40 \\
\hline $\mathrm{K}^{+}\left(\mathrm{mg} \cdot \mathrm{l}^{-1}\right)$ & 0.72 & 0.42 & 0.08 & -0.12 & 0.48 & 0.54 & 0.21 & 0.14 & -0.43 & 0.62 & 0.24 & 0.50 & -0.03 & 0.20 & 0.65 & 0.23 & -0.31 & 0.76 & 0.20 & 0.07 & -0.16 \\
\hline $\mathrm{Ca}^{2+}\left(\mathrm{mg} \cdot \digamma^{-1}\right)$ & 0.76 & 0.28 & 0.14 & 0.14 & 0.30 & 0.51 & -0.30 & -0.21 & -0.30 & 0.82 & 0.00 & -0.11 & 0.05 & -0.27 & 0.78 & 0.12 & 0.08 & 0.86 & 0.05 & 0.24 & 0.14 \\
\hline $\mathrm{Mg}^{2+}\left(\mathrm{mg} \cdot \mathrm{l}^{-1}\right)$ & 0.89 & 0.12 & 0.00 & -0.09 & 0.76 & 0.38 & 0.04 & -0.12 & -0.37 & 0.83 & 0.04 & 0.11 & -0.14 & 0.17 & 0.78 & 0.07 & -0.13 & 0.77 & 0.34 & -0.38 & 0.08 \\
\hline $\mathrm{Fe}^{2+}\left(\mathrm{mg} \cdot \mathrm{I}^{-1}\right)$ & 0.00 & 0.05 & -0.34 & 0.75 & -0.12 & -0.07 & -0.09 & 0.86 & 0.05 & -0.03 & 0.04 & -0.07 & 0.06 & 0.88 & -0.24 & 0.60 & 0.04 & -0.12 & 0.28 & 0.69 & -0.25 \\
\hline $\mathrm{Mn}^{2+}\left(\mathrm{mg} \cdot \cdot^{-1}\right)$ & -0.23 & 0.19 & 0.28 & 0.76 & 0.02 & 0.45 & 0.44 & 0.61 & -0.20 & 0.19 & 0.21 & 0.28 & 0.60 & 0.46 & 0.25 & 0.70 & -0.02 & 0.14 & -0.10 & 0.87 & 0.22 \\
\hline $\mathrm{Zn}^{2+}\left(\mathrm{mg} \cdot \mathrm{l}^{-1}\right)$ & 0.11 & 0.23 & -0.08 & 0.73 & -0.15 & 0.24 & 0.15 & 0.63 & 0.32 & -0.07 & 0.17 & -0.16 & 0.69 & 0.01 & -0.07 & 0.76 & 0.17 & -0.06 & 0.32 & 0.76 & 0.08 \\
\hline $\mathrm{H}^{+}\left(\mu \mathrm{g} \cdot \Gamma^{-1}\right)$ & -0.43 & 0.32 & -0.62 & -0.07 & -0.02 & 0.14 & 0.01 & 0.13 & 0.88 & -0.02 & -0.03 & -0.84 & 0.26 & -0.03 & 0.00 & 0.00 & 0.92 & 0.04 & -0.07 & 0.06 & 0.81 \\
\hline Eigenvalue & 3.01 & 2.51 & 1.36 & 1.91 & 2.68 & 3.47 & 1.44 & 1.06 & 1.21 & 2.07 & 1.59 & 1.18 & 3.74 & 1.08 & 2.26 & 4.42 & 1.28 & 4.20 & 1.15 & 2.55 & 1.34 \\
\hline $\begin{array}{l}\text { Explained variance } \\
\qquad(\%)\end{array}$ & 27.71 & 19.98 & 11.43 & 8.48 & 20.59 & 26.72 & 11.09 & 8.14 & 9.30 & 15.95 & 12.28 & 9.07 & 28.76 & 8.28 & 17.38 & 34.03 & 9.85 & 32.30 & 8.82 & 16.64 & 10.33 \\
\hline $\begin{array}{l}\text { Cumulative } \\
\text { explained variance } \\
(\%)\end{array}$ & 27.71 & 47.69 & 59.12 & 67.60 & 20.59 & 47.31 & 58.40 & 66.54 & 75.84 & 15.95 & 28.23 & 37.30 & 66.06 & 74.34 & 17.38 & 51.41 & 61.26 & 32.30 & 41.12 & 57.76 & 68.09 \\
\hline Factors & \multicolumn{4}{|c|}{$\begin{array}{l}\text { PC1 - "mineral dust" } \\
\text { PC2 - "acidic emissions" } \\
\text { PC3 - "ammonium" } \\
\text { PC4 - "heavy metals-dust } \\
\text { particles" }\end{array}$} & \multicolumn{5}{|c|}{$\begin{array}{l}\text { PC1 - "mineral dust" } \\
\text { PC2 - "acidic emissions" } \\
\text { PC3 - "ammonium" } \\
\text { PC4 - "heavy metals-dust } \\
\text { particles" }\end{array}$} & \multicolumn{5}{|c|}{$\begin{array}{l}\text { PC1 - "mineral dust" } \\
\text { PC2 - "acidic emissions" } \\
\text { PC3 - "ammonium" } \\
\text { PC4 - "heavy metals-dust } \\
\text { particles" }\end{array}$} & \multicolumn{3}{|c|}{$\begin{array}{l}\text { PC1 - "mineral } \\
\text { dust" } \\
\text { PC2 - "acidic } \\
\text { emissions" + } \\
\text { "heavy metals-dust } \\
\text { particles" }\end{array}$} & \multicolumn{4}{|c|}{$\begin{array}{l}\text { PC1 - "mineral dust" } \\
\text { PC2 - "acidic emissions" } \\
\text { PC4- "heavy metals-dust } \\
\text { particles" }\end{array}$} \\
\hline
\end{tabular}

* The four stand age categories correspond to stands 11, 24, 91 and 116 years old.

Note: $\quad$ PC1, PC2, PC3, PC4, PC5 (regular) - primary notation connected with sequence of PCs obtained by PCA; $P C 1, P C 2, P C 3, P C 4, P C 5$ (italic) - changed notation to unify the factor identification.

both "acidic emissions" and "heavy metals-dust particles" sources. For BP and the $1^{\text {st }}$ and $2^{\text {nd }}$ categories in the factor layout, there was a factor strongly influenced by $\mathrm{NH}_{4}{ }^{+}$that explains $11.43,11.09$, and $9.07 \%$ of the total variance, respectively. The $\mathrm{NH}_{4}{ }^{+}$present in the atmosphere might come from several sources including the volatilization of animal residues, human excrements, natural loss by plants, biomass burning, and industrial processes, such as the use or the production of fertilizers and emissions from the combustion of fossil fuels[27,28]. For the $5^{\text {th }}$ and $6^{\text {th }}$ categories, the influence of $\mathrm{NH}_{4}{ }^{+}$is connected with variables belonging to the "acidic emissions" factor.

Concentration of major analytes classified as components of identified factors were summarized ("acidic emissions", $\mathrm{SO}_{4}{ }^{2-}, \mathrm{NO}_{3}^{-}$; "heavy metals-dust particles", $\mathrm{Fe}^{2+}, \mathrm{Mn}^{2+}, \mathrm{Zn}^{2+}$; "natural", $\mathrm{Na}^{+}, \mathrm{K}^{+}, \mathrm{Ca}^{2+}$; " $\mathrm{NH}_{4}{ }^{+} "$; and $\mathrm{H}^{+}$) and presented in Fig. 3, taking into account the division of throughfall into winter and the growing season (vertical lines represent \pm S.D.). The particular coefficients of determination for winter season and all year can be summarized as follows: "acidic emissions" (winter: $\mathrm{R}^{2}=0.99$, all: $\mathrm{R}^{2}=0.91$ ); "heavy metals-dust particles" (winter: $\mathrm{R}^{2}=0.72$, all: $\mathrm{R}^{2}=0.54$ ); "mineral dust" (winter: $\mathrm{R}^{2}=0.98$, all: $\mathrm{R}^{2}=$ 0.87); " $\mathrm{H}^{+}$" (winter: $\mathrm{R}^{2}=0.97$, all: $\mathrm{R}^{2}=0.93$ ); " $\mathrm{NH}_{4}{ }^{+}$" (winter: $\mathrm{R}^{2}=0.81$, all: $\mathrm{R}^{2}=0.91$ ). As the age of the spruce stands increased together with differences in canopy structure and leachability of foliage with a larger component of older foliage, the sum of anions of strong acids and concentrations of $\mathrm{H}^{+}$ 


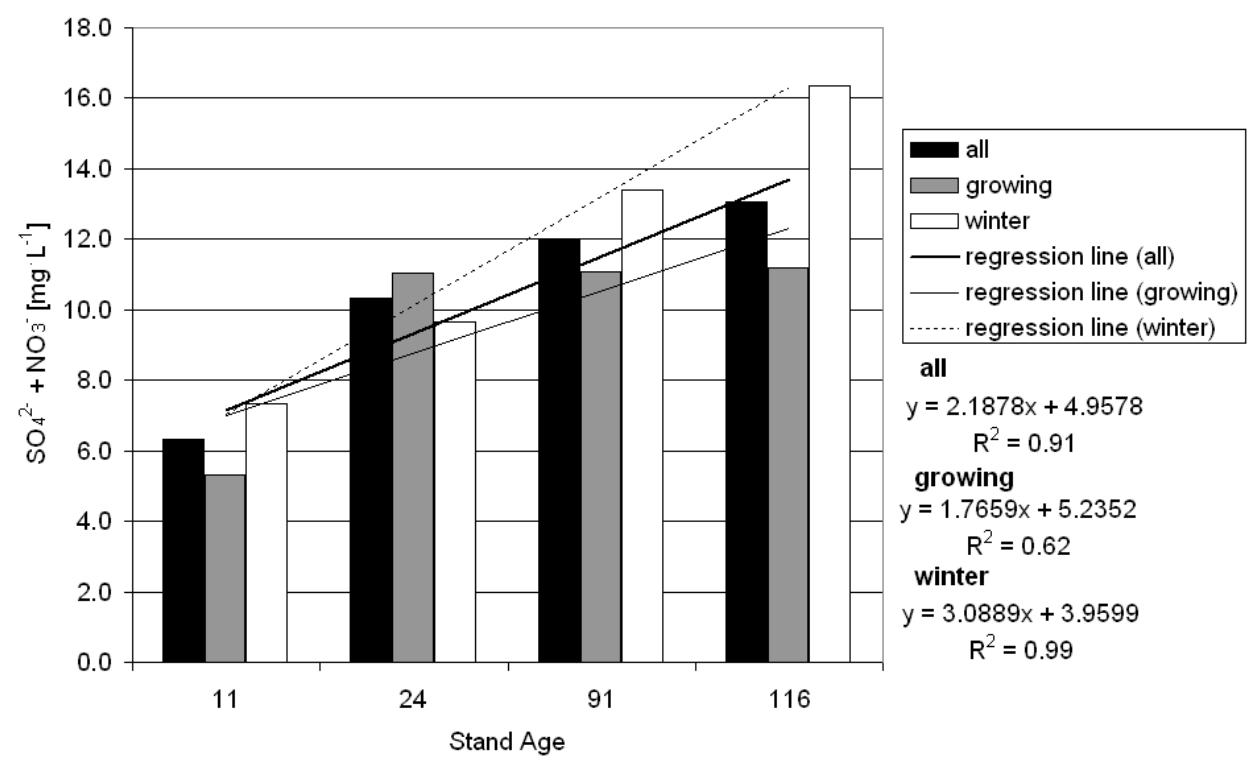

A

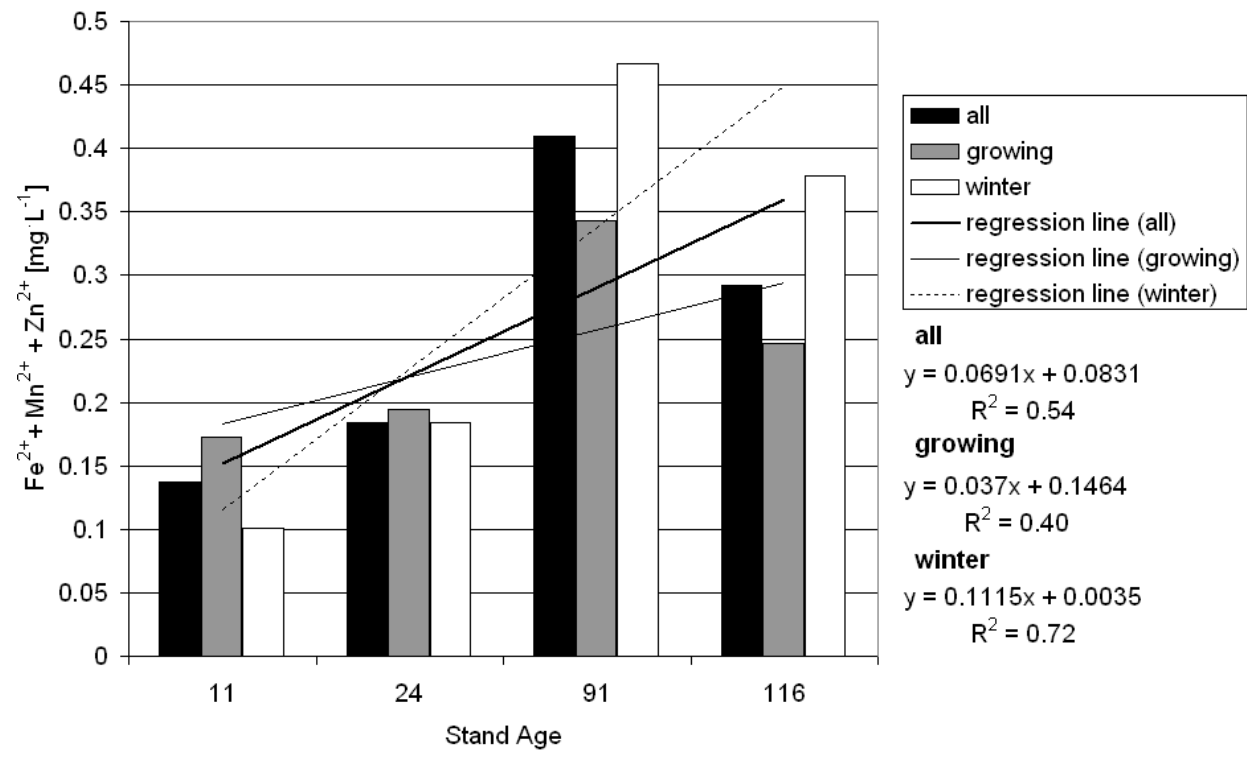

B

FIGURE 3. Linear regressions of (A) $\Sigma\left(\mathrm{SO}_{4}{ }^{2-}+\mathrm{NO}_{3}^{-}\right)$, (B) $\Sigma\left(\mathrm{Fe}^{2+}+\mathrm{Mn}^{2+}+\mathrm{Zn}^{2+}\right)$, (C) $\Sigma\left(\mathrm{Na}^{+}+\mathrm{K}^{+}+\mathrm{Ca}^{2+}+\right.$ $\mathrm{Mg}^{2+}$ ), (D) $\mathrm{H}^{+}$, (E) $\mathrm{NH}_{4}{ }^{+}$in throughfall for four Norway spruce (P. abies Karst) stand age categories for the whole year, and during the winter and growing seasons.

increased over the whole year, and especially in winter. The same tendency was also noticed for the sum of cations and heavy metals in winter. During the growing season, this relationship was not so strong, probably because solutions were modified by processes occurring in the canopy (adsorption, leaching, etc.). Concentrations of $\mathrm{NH}_{4}{ }^{+}$and $\mathrm{H}^{+}$increased with the age of spruce stands in winter and during the growing season. This is of particular concern because of likely increases in nitrification rates and soil acidification. Excess nitrogen and increasing $\mathrm{N} /$ cation ratios may have negative effects on the health condition of spruce stands[29]. A decrease in the $\mathrm{pH}$ of BP and throughfall solutions as a stand ages can have an effect on the soil neutralizing capacity[22]. 


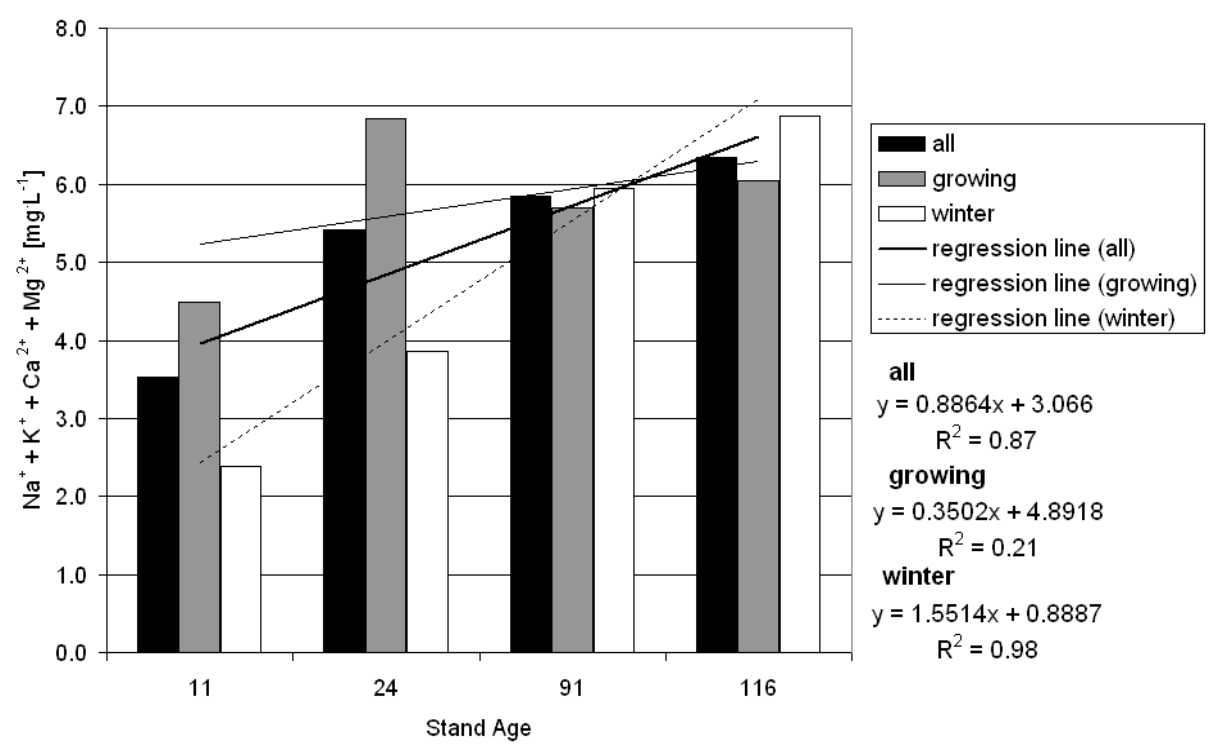

FIGURE 3C

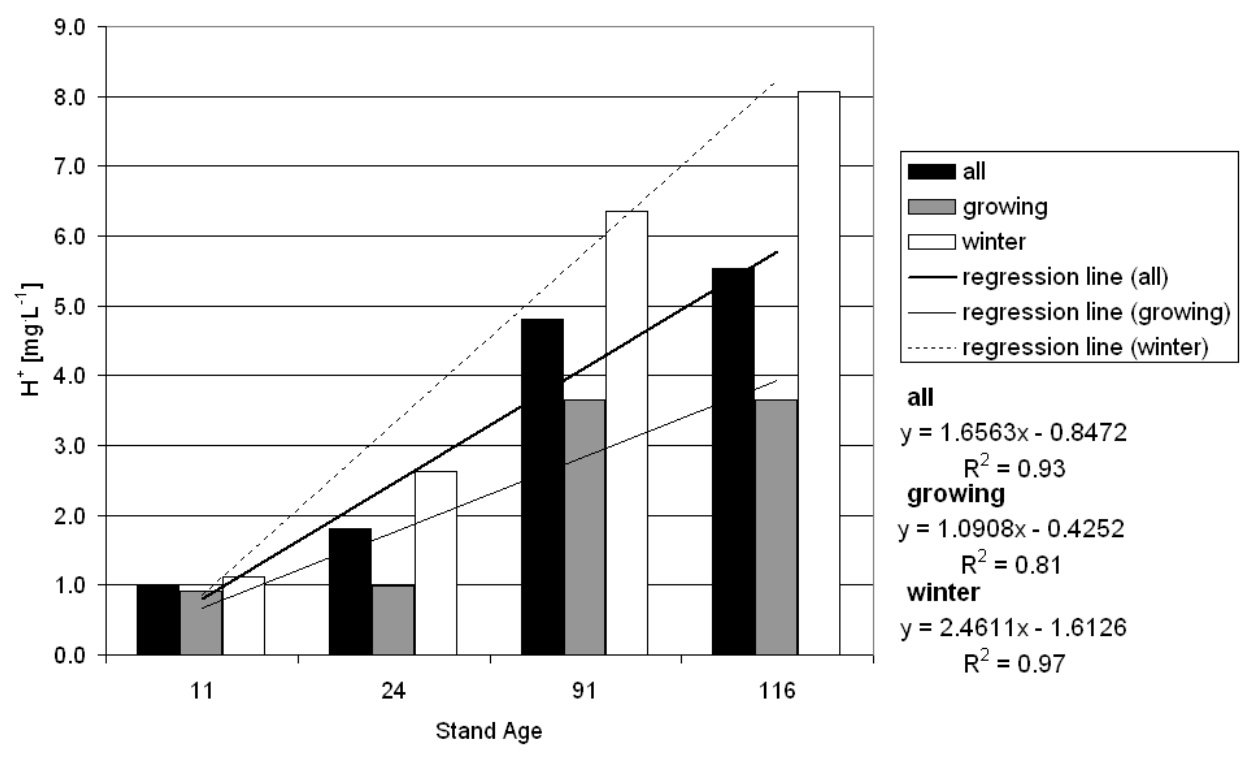

FIGURE 3D

\section{CONCLUSION}

1. The chemical composition of throughfall solutions depends on the age of the spruce stands and season of the year. A decrease in the $\mathrm{pH}$ of throughfall and an increase in the amount of hydrogen ion deposited to the soil in throughfall with increasing stand age were especially noted in the winter season.

2. Concentrations in throughfall of $\mathrm{K}^{+}, \mathrm{H}^{+}, \mathrm{SO}_{4}{ }^{2-}, \mathrm{Mn}^{2+}$, and $\mathrm{NH}_{4}{ }^{+}$were greater than in $\mathrm{BP}$ over the whole year, and in winter and the growing seasons, concentrations of $\mathrm{K}^{+}, \mathrm{H}^{+}$, and $\mathrm{Mn}^{2+}$ were greater in throughfall. This suggests that these ions were washed out or washed from the surface of needles and/or the bark. The other ions $\mathrm{NO}_{3}{ }^{-}, \mathrm{NH}_{4}^{+}, \mathrm{Ca}^{2+}, \mathrm{Mg}^{2+}$ (especially in vegetation period), $\mathrm{Fe}^{2+}$, and $\mathrm{Zn}^{2+}$ were absorbed in the canopy, especially in older Norway spruce stands. 


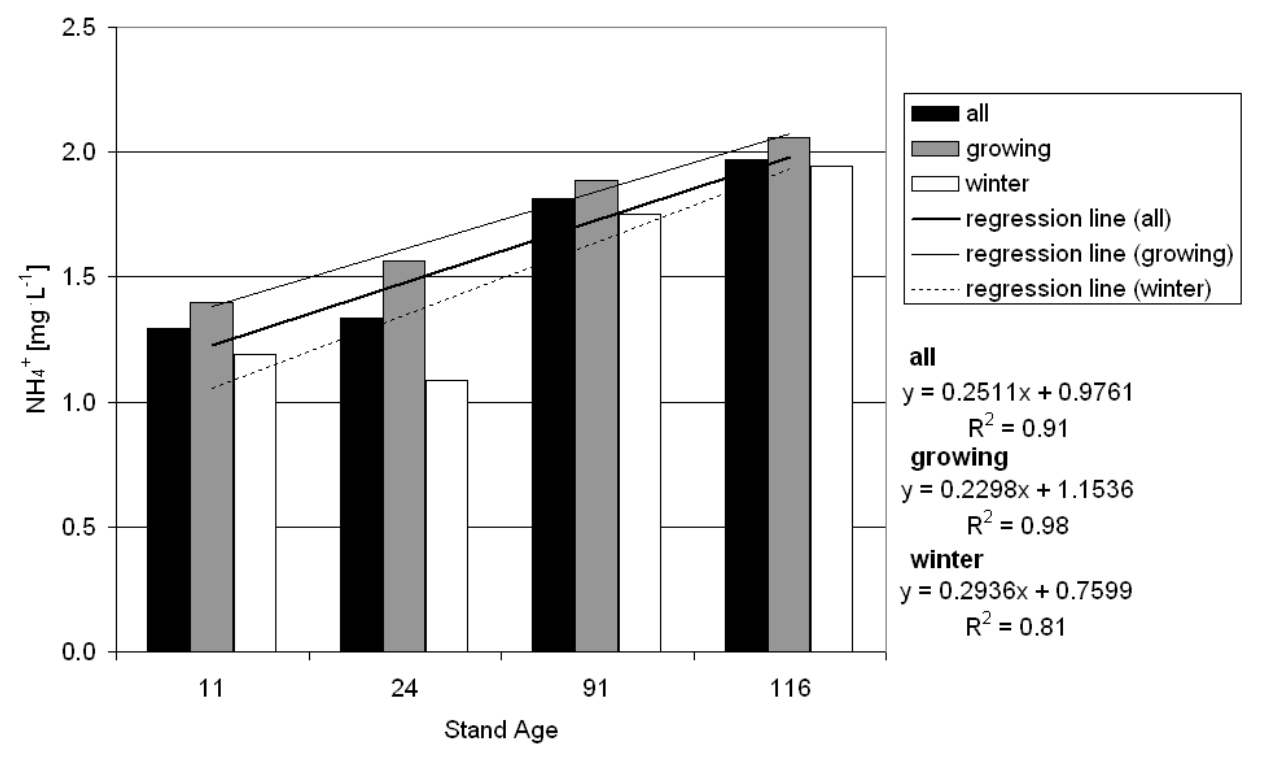

FIGURE 3E

3. Nitrogen deposition was above critical loads for coniferous trees, which may change $\mathrm{N} /$ macronutrient ratios, decrease $\mathrm{K}$ and $\mathrm{Mg}$, and increase $\mathrm{N}$ concentration in foliar tissue, and which may be an increasing problem in the future unless emissions of nitrogen oxides, and especially $\mathrm{NH}_{4}^{+}$, are reduced.

4. A 5-year throughfall study on the Dupniański catchment indicated an increasing amount of sulfur and of the sum of the strong acids $\left(\mathrm{S}_{-} \mathrm{SO}_{4}{ }^{2-}\right.$ and $\left.\mathrm{N}-\mathrm{NO}_{3}{ }^{-}\right)$deposited to the soil, especially in older spruce age classes, which may have implications for the vitality of spruce stands.

5. The application of PCA has led to identification in general of five factors responsible for the data structure ("mineral dust", "acidic emissions", "heavy metals-dust particles", "NH${ }_{4}^{+}$", and " $\mathrm{H}^{+}$"). They explain $61-76 \%$ of the total variance system for BP and the $1^{\text {st }}, 2^{\text {nd }}, 5^{\text {th }}$, and $6^{\text {th }}$ spruce age classes. The percentage of variance explained refers not to some definitive environmental events, but to the validity of the multivariate statistical model, which tries to indicate possible sources of the deposited ions.

6. The strong positive correlation between spruce age classes and ionic concentrations in throughfall occurs for all year and the winter period for ions within the following categories: "acidic emissions": $\mathrm{SO}_{4}{ }^{2-}+\mathrm{NO}_{3}^{-}$; "heavy metals-dust particles": $\mathrm{Fe}^{2+}+\mathrm{Mn}^{2+}+\mathrm{Zn}^{2+}$; "mineral dust": $\mathrm{Na}^{+}$ $+\mathrm{K}^{+}+\mathrm{Ca}^{2+}+\mathrm{Mg}^{2+}$; " $\mathrm{NH}_{4}^{+}$"; and " $\mathrm{H}^{+}$". The strength of the relationship decreases in the growing period, probably due to the processes occurring in the canopy (adsorption, leaching, etc.).

\section{REFERENCES}

1. Małek, S. (2004) The effect of the age of spruce stands on the balance of elements in the Potok Dupnianski catchment. Dendrobiology 51, 61-66.

2. Staszewski, T., Godzik, S., Kubiesa, P., and Szdzuj, J. (1999) Fate of nitrogen compounds deposited to spruce (Picea abies Karst.) and pine (Pinus silvestris L.) forests located in different air pollution and climatic conditions. Water Air Soil Pollut. 116, 121-127.

3. Bytnerowicz, A., Godzik, S., Poth, M., Anderson, I., Szdzuj, J., Tobias, C., Macko, S., Kubiesa, P., Staszewski, T., and Fenn M. (1999) Chemical composition of air, soil and vegetation in forests of the Silesian Beskid Mountains, Poland. Water Air Soil Pollut. 116, 141-150.

4. Rothe, A., Huber, C., Kreutzer, K., and Weis, W. (2002) Deposition and soil leaching in stands of Norway spruce and European beech: results from the Hoglwald research in comparison with other European case studies. Plant Soil 240(1), 33-45.

5. Wróbel, S. (1998) Environmental degradation in the Black Vistula and White Vistula catchments, Western 
Carpathians. Stud. Nat. 44, 1-223.

6. Jussy, J.H., Colin-Belgrand, M., Dambrine, E., Ranger, J., Zeller, B., and Bienaime, S. (2004) N deposition, N transformation and N leaching in acid forest soils. Biogeochemistry 69(2), 241-262.

7. Bytnerowicz, A., Godzik, B., Frączek, W., Grodzińska, K., Krywult, M., Bada, O., Barančok, P., Blum, O., Čzerny, M., Godzik, S., Maňkovská, B., Manning, W., Moravčik, P., Musselman, R., Oszlányi, J., Postelnicu, D., Szdżuj, J., Varšavova, M., and Zota, M. (2002) Ozone, sulphur dioxide and nitrogen dioxide air pollution in forests of the Carpathian Mountains. In Effects of Air Pollution on Forest Health and Biodiversity in Forests of the Carpathian Mountains. Szaro, R.C. et al. Eds. IOS Press. pp. 138-160.

8. Maňkovská, B., Čzerny, M., Moravčik, P., Godzik, B., Grodzińska, K., Badea, O., Barančok, P., Oszlányi, J., Varšavova, M., Fleischer, P., Blum, O., Parpan, V., Bytnerowicz, A., and Szaro, R. (2002) Chemical and morfological changes in Carpathian Mountains trees caused by air pollution. In Effects of Air Pollution on Forest Health and Biodiversity in Forests of the Carpathian Mountains. Szaro, R.C. et al. Eds. IOS Press. pp. 173-184.

9. ICP-Forest Manual (1998) Manual on Methods and Criteria for Harmonized Sampling, Assessment, Monitoring and Analysis of the Effects of Air Pollution on Forests. 6th ed. UN-ECE, Fed. Res. Centre for Forestry and Forest Products (BFH).

10. Astel, A., Mazerski, J., Polkowska, Ż., and Namieśnik, J. (2004) Application of PCA and time series analysis in studies of precipitation in Tricity (Poland). Adv. Environ. Res. 8, 337-349.

11. IUPAC Compendium of Chemical Terminology, $2^{\text {nd }}$ (1997) www.iupac.org/goldbook/L03540.pdf

12. StatSoft, Inc. (2001) STATISTICA (Data Analysis Software System). Version 6. www.statsoft.com.

13. Mackiewicz, A. and Ratajczak, W. (1993) Principal components analysis (PCA). Comput. Geosci. 19, $303-342$.

14. Lovett, G.M. and Schaefer, D.A. (1992) Interaction of $\mathrm{Ca}^{2+}, \mathrm{Mg}^{2+}$ and $\mathrm{K}^{+}$. In Atmospheric Deposition and Forest Nutrient Cycling. Johnson, D.W. and Lindberg, S.E., Eds. Springer Verlag. pp. 217-240.

15. Zimka, J.R. and Stachurski, A. (1996) Forest decline in Karkonosze Mts. (Poland). Part II. An analysis of acidity and chemistry of atmospheric precipitation, throughfall and forest stream waters. Pol. Ecol. 44(1-2) 153-177.

16. Kabata-Pendias, A. and Pendias, H. (2000) Trace Elements in Soil and Plants. $2^{\text {nd }}$ ed. CRC Press.

17. Polkowska, Ż., Astel, A., Walna, B., Małek, S., Mędrzycka, K., Górecki, T., Siepak, J., and Namieśnik, J. (2005) Chemometric analysis of rain water and throughfall at several sites in Poland. Atmos. Environ. 39, 837-855.

18. Stachurski, A. (1987) Nutrient control in throughfall waters of forest ecosystems. Pol. Ecol. 35(1), 3-69.

19. Hultberg, H. and Ferm, M. (2004) Temporal changes and fluxes of sulphur and calcium in wet and dry deposition, internal circulation as well as in run-off and soil in a forest at Gårdsjön, Sweden. Biogeochemistry 68(3), 355-363.

20. Hall, J. (2004) Mapping Critical Loads. Manual on Methodologies and Criteria for Modelling and Mapping Critical Loads and Levels and Air Pollution Effects, Risk and Trends. www.icpmapping.org

21. Černý, J., Havel, M., and Krejýí, R. (1997) Bulk deposition and throughfall fluxes in the Ore Mts. - decreasing atmospheric deposition into Norway spruce stands. J. For. Sci. (Prague) 45(4), 153-162.

22. Małek, S., Martinson, L., and Sverdrup, H. (2005) Modeling future soil chemistry at a highly polluted forest site at Istebna in Southern Poland using the "SAFE" model. Environ. Pollut. 3(137), 568-573.

23. Małek, S. (2002) The importance of litterfall and needle nutrients in circulation of elements and sustaining long-term productivity - example from different age classes of Istebna Spruce stands in the Potok Dupnianski catchment, southern Poland. Reports in Ecology and Environmental Engineering 2002 (1), Sustainable Forestry in Temperate Regions. Proceedings of the SUFOR International Workshop, Lund, Sweden, 7-9 April, 2002. pp. 124-130.

24. Alewell, C., Manderscheid, B., Gerstberger, P., and Matzner, E. (2000) Effects of reduced atmospheric deposition on soil solution chemistry and elemental contents of spruce needles in NE-Bavaria, Germany. J. Plant Nutr. Soil Sci. 163(5), 509-516.

25. Al-Khashman, O.A. (2005) Ionic composition of wet precipitation in the Petra Region, Jordan. Atmos. Environ. 78(12), 1-12.

26. Tang, A., Zhuang, G., Wang, Y., Yuan, H., and Sun, Y. (2005) The chemistry of precipitation and its relation to aerosol in Beijing. Atmos. Environ. 39, 3397-3406.

27. Spanos, Th., Simeonov, V., and Andreev, G. (2002) Environmetric modeling of emission sources for dry and wet precipitation from an urban area. Talanta 58, 367-375.

28. Ugucione, C., Felix, E.P., Rocha, G.O., and Cardoso, A.A. (2002) Daytime and nighttime removal processes of atmospheric $\mathrm{NO}_{2}$ and $\mathrm{NH}_{3}$ in Araraquara's region-SP. Eclect. Quim. 27, 1-9.

29. Niemtur, S., Małek, S., Pierzgalski, E., Staszewski, T., and Wójcik, J. (2005). Nutrient cycling in artificial mountain spruce stands as a background for conversion and sites degradation in the Silesian Beskid. In Protection of Soil and Water Resources in Forestry Areas. Pierzgalaski, E., Niemtur, S., and Czerepko, J., Eds. Warsaw. pp. 93-102.

\section{This article should be cited as follows:}

Małek, S. and Astel, A. (2007) The effect of stand age on throughfall chemistry in spruce stands in the Potok Dupniański catchment in the Silesian Beskid Mountains, southern Poland. TheScientificWorldJOURNAL 7(S1), 181-191. DOI 10.1100/tsw.2007.90. 

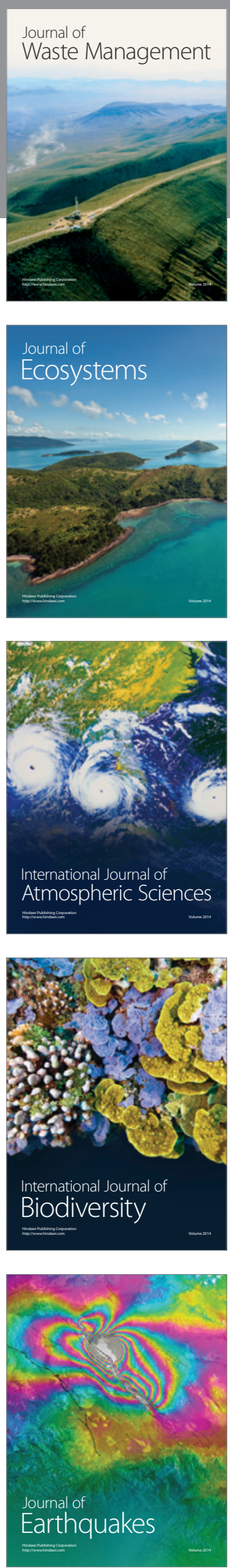
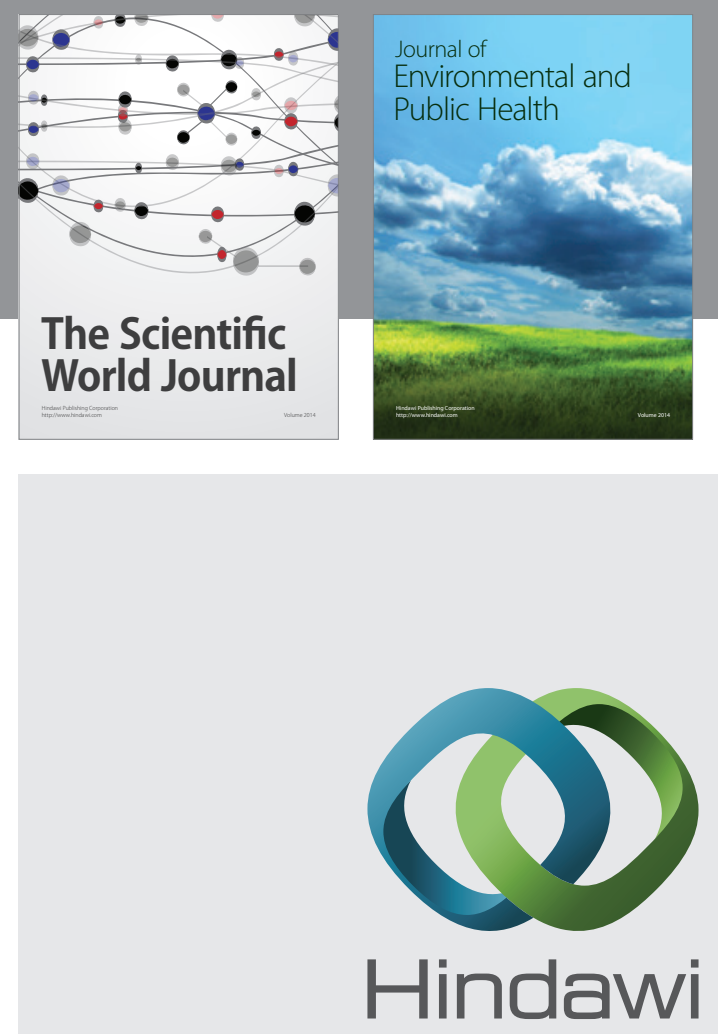

Submit your manuscripts at

http://www.hindawi.com
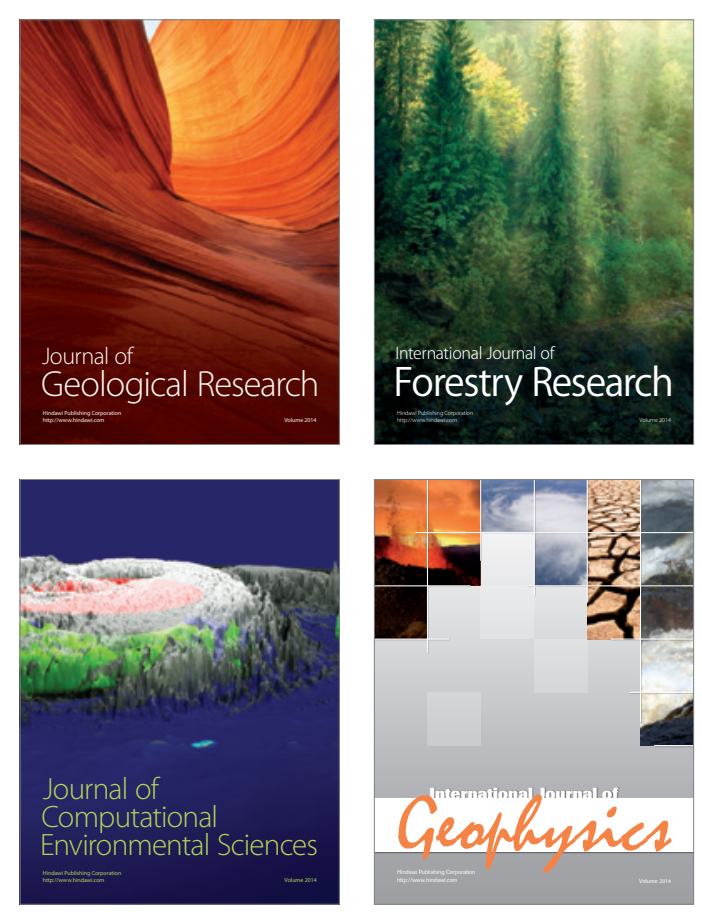
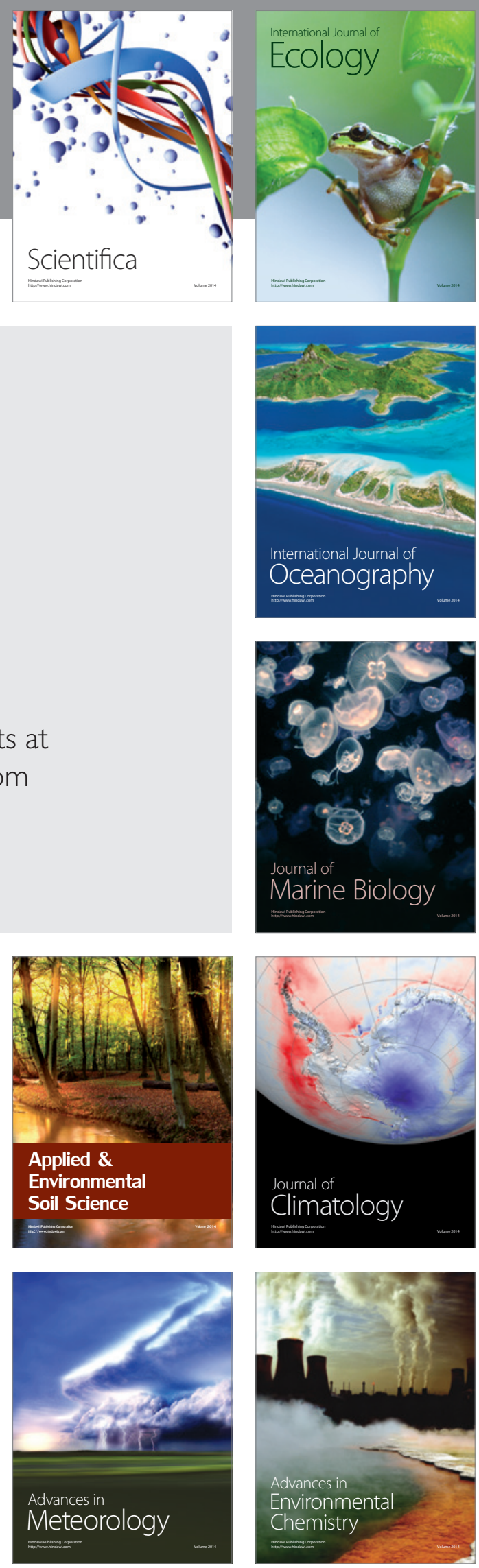